\title{
Knowledge and Practice regarding Waste Management among Community People of Gokarneshwor Ward-05, Nepal
}

\author{
Doma Sherpa* and Sumita Pathak \\ Purbanchal University, Kathmandu, Nepal \\ *Correspondence: domasherwa@gmail.com \\ Type of the Paper (Article) \\ Received: May 6, 2019; Accepted: June 26, 2019; Published: September 01, 2019 \\ https://doi.org/10.29253/achnr.2019.13825
}

\begin{abstract}
This descriptive study entitled "Knowledge and practice regarding waste management among community people of Gokarneshwor. The objective of this study is to assess the level of knowledge and practice regarding waste management among community people. A total number of 87 respondents were selected by using probability simple random sampling technique of lottery method. Sample size was 60 respondents from 60 household which were selected by using nonprobability purposive sampling technique from Prabhuram Colony ward-05, Gokarneshwor, Kathmandu. Data were collected by face to face interview by using semi structured interview schedule. The obtained data were analyzed by using descriptive statistics and inferential statistics. Out of 60 respondents, $23.33 \%$ respondents were illiterate and half of the respondents were engaged in household work. Majority $(86.70 \%)$ respondents answered waste as unwanted or unusable things. The study reveals that majority $98.30 \%$ of respondents had moderate level of knowledge on waste management whereas only $41.70 \%$ respondents had good practice level. The study concluded that majority respondent had moderate level of knowledge whereas majority of respondent had poor practice level. The study shows that there is no association between knowledge and practice. Different awareness and intervention program must be carried out in the community to improve the practice of people regarding waste management and to improve the waste management system.
\end{abstract}

Keywords: knowledge; waste; community people

\section{Introduction}

Waste is defined as any discarded material, which has no value in normal use or for ordinary use. Generation of wastes is inevitable. Waste can take any form that is solid, liquid, or gas and each have different methods of disposal and management. Municipal or household wastes are often generated from several sources where variable human activities are encountered. Several studies indicate that much of the municipal solid waste from developing countries are generated from households (55-80\%), followed by commercial or market areas (10-30\%) with varying quantities from streets, industries, institutions among others (Babaei, et al 2015; Abikusno, 2003; Bernardo, 2008).

In United Kingdom 2004/2005 for instance, it was estimated that out of, 36 million tons of municipal waste generated, 30 million tons was collected from households. Current waste generation in Bangladesh 
is around 22.4 million tons per year or $150 \mathrm{~kg} / \mathrm{cap} /$ year. There is an increasing rate of waste generation in Bangladesh and it is projected to reach 47, 064 tons per day by 2025_(Bhuiyan,2010). Javadekar has stated that India will, in another couple of decades, generate nearly thrice the waste it currently does "165 million tons by 2030 and 450 million tons by 2050." Only 22-28 percent of the waste now collected is processed or treated (Das and Das, 2017). A survey conducted by Asian Development Bank in all 58 municipalities of Nepal in 2012 found that the average municipal solid waste generation was 317 grams per capita per day. This translates into 1,435 tons per day or 524,000 tons per year of municipal solid waste generation in Nepal (Asian Development Bank, 2013). In this 21st century, waste management is part of the important service, which is sustaining our society especially in urban area. It has now become basic human right, which is part of basic human needs (Guerrero, 2013).

Waste management is a growing problem in Nepal. For this reason the government of Nepal and different NGOS are have taken various measures to promote for reusing and recycling of waste amongst its population (Asian Development Bank, 2013).

Waste management is intended to reduce adverse effects of waste on health and the environment. Waste management practices are not uniform among countries, regions and sectors (Barloa, Lapie, \& de la Cruz, 2016). The management of waste should focus on how to find the value and redirect it back to the community. But unfortunately, the collecting and dumping process mix and crush everything together; and make separation an expensive and sometimes impossible task to properly manage wastes (Laor, et al. 2018; Pandey,2004; Pokhrel \& Viraraghavan, 2005). Poor Domestic waste management also displays an ugly scenario of the environment (Iwu et al. 2016; Jin, Wang,, \& Ran, 2006). Some of the waste on the other hand may also contain poisonous substances like Mercury, lead, cadmium from batteries, old medicines, household cleaning \& Decorating chemicals and garden chemicals (Shekdar, 2009). We can conclude that majority of the problem can be avoided if the household waste is properly managed.

\section{Objectives}

General objective: to assess the knowledge and practice regarding waste management among community people.

Specific objectives:

- To find out the knowledge regarding waste management of community people.

- To identify the practices regarding waste management of community people

- To find out the association between knowledge and practice regarding waste management

\section{Methods}

\subsection{Research Design}

Descriptive, cross- sectional study design was used while conducting this study among community people of Prabhuram Colony,_Gokarneshwor Ward-5.

\subsection{Research Area/Setting}

Prabhuram Colony, Gokarneshwor ward no.5. was the research area. In this colony there are total 60 households and there is poor practice related waste management in this area which have brought negative impact on the health of the community people living there.

\subsection{Study Population and Sample}

One member from one house of Prabhuram Colony, Gokarneshwor ward -5 was the study population. The total Household of Prabhuram Colony, Gokarneshwor ward -5 is 60 .

Sample size

The total Household (n) $=60$

The sample for the study will be collected in 60 households of People living in Prabhuram Colony, Gokarneshwor Ward -5.

Sampling technique

Purposive sampling technique was used to select the area and sample for the study. 
Inclusion Criteria: The total household will be included during data collection period. Exclusion Criteria: People who cannot communicate will be excluded.

\subsection{Research Instruments/Tools}

A semi-structured questionnaire was developed and interview method was used to measure the research variable regarding knowledge and practice regarding waste management among community people. Researcher herself in simple and understandable language developed the questionnaire. The interview schedule was divided into three parts:

1. Demographic data (age, sex, family type, size of family, educational level, occupation)

2. Knowledge related questions about waste management (waste, types of waste, effect of waste, method of disposal)

3. Practice related questions about waste management

Review of literature, and consultation experts was done to maintain the content validity. Simple and understandable language was used in the questionnaire for obtaining response from the respondents. Questionnaire was developed in English and translated to Nepali language with the help of Nepali translator for the convenience of the respondents. Reliability was maintained by pretesting of the question in $10 \%$ of the sample size at Ramkot, Kathmandu Community. The study tool was revised and finalized on the basis of results obtained from pretest.

\subsection{Data Collection Procedure}

The researcher used different approach of data collection that was guided by objectives.

- Data collection was conducted in community

- Purpose of the study was explained at first to the community people.

- Written consent was taken with the participants.

- Data was collected using interview technique

- 30 minutes time was provided to answer the questions.

- After 30 minutes collected questionnaire was privately handled.

- Data was collected from 1st -30th Shrawan

\subsection{Ethical consideration}

\section{Permission}

The approval to perform research was taken from concerned authority of ethical board of Kathmandu model hospital.

Informed consent

- The purpose and objectives of study was explained in clear and understandable terms to the respondent.

- Full information about the research was given to students.

- Nobody was forced for participation.

Anonymity

- Anonymity was established as the study will not collect identifying information of individual subjects (e.g., name, address, Email address, etc.) and will use code number as 1,2,3.

- Confidentiality

- It was maintained by not disclosing their information.

- Information was used only for research purpose.

Security

Privacy was maintained by preserving the filled questionnaire in locked cupboard until three years.

No discrimination 
Human rights and justice were maintained during the study of population without any discrimination of age, ethnicity, and socio-economic condition.

\subsection{Data processing and analysis technique}

- The collected data was check and organized for completeness and accuracy.

- Any errors, incompleteness and inconsistencies in the data that could distort the result of the study were removed.

- The data was coded and analyzed using computer package with software SPSS (Statistical Package for Social Science) version 20.

- Frequency and percentage was calculated to measure socio-demographic variable.

- Percentage, mean, standard deviation was used to measure the level knowledge among community people

- Chi-square test was used to show the association between knowledge and practice

- The data was presented in tabular form

\section{Results}

The data obtained from 60 households for exploring knowledge and practice regarding waste management among community people of Gokarneshwor ward 5 is presented on the tables to facilitate interpretation. The data were analyzed according to the research objectives. This chapter is divided into three parts: socio-demographic information of respondents, knowledge regarding waste management, practice regarding waste management.

\subsection{Socio-demographic Information}

The following table contains the socio-demographic information of the participants which includes age, gender, education, family type, and occupation.

Table1. Socio-demographic characteristics of respondents $(n-=60)$.

\begin{tabular}{lrr}
\hline Description & Number & Percent \\
\hline Age in completed years & & \\
Young adulthood (18-40) & 37 & 61.70 \\
Middle adulthood (40-65) & 22 & 36.7 \\
Elder (>65 years) & 1 & 1.7 \\
Gender & & \\
$\quad$ Female & 41 & 68.30 \\
Male & 19 & 31.70 \\
Education & & \\
Basic Education & 7 & 11.70 \\
Secondary Education & 30 & 50.00 \\
Higher Education & 9 & 15.00 \\
Illiterate & 14 & 23.33 \\
Type of family & & \\
Nuclear family & 50 & 83.30 \\
Joint Family & 7 & 11.70 \\
Extended Family & 3 & 5.00 \\
Occupation & & \\
Household & 31 & 51.70 \\
Agriculture & - & - \\
Service & 7 & 11.70 \\
Laborer & 5 & 8.30 \\
Business & 17 & 28.30 \\
\hline
\end{tabular}


Table 1 shows that the $37(61.70 \%)$ respondents were of age group 18-40 in which $41(68.30 \%)$ Female and $19(31.70 \%)$ male had participated in the study. Out of 60 respondents, 30 (50\%) respondents had secondary education whereas 14 (23.33\%) respondents were Illiterate. 50 (83.30\%) respondents were from Nuclear family and half of the respondents were engaged in Household work.

\subsection{Knowledge regarding Waste Management}

Table 2 shows knowledge regarding waste; majority 52 (86.70\%) respondents answered waste as unwanted or unusable things. Majority 54 (90\%) respondents answered Health care area as common area of waste generation.

Table 2. Knowledge regarding waste $(n=60)$.

\begin{tabular}{|c|c|c|}
\hline Description & Number & Percent \\
\hline \multicolumn{3}{|l|}{ Meaning* } \\
\hline Unwanted or unusable things & 52 & 86.70 \\
\hline Items discarded by the people & 44 & 73.30 \\
\hline $\begin{array}{l}\text { Waste that can cause harm to human and the } \\
\text { environment }\end{array}$ & 37 & 61.70 \\
\hline Peelings of fruits and vegetables & 43 & 71.70 \\
\hline \multicolumn{3}{|l|}{ Source of waste generation* } \\
\hline Municipal waste & 52 & 86.70 \\
\hline Industrial & 52 & 86.70 \\
\hline Institutional & 39 & 65.00 \\
\hline Agriculture & 48 & 80.00 \\
\hline Health care & 54 & 90.00 \\
\hline Commercial wastes & 43 & 71.70 \\
\hline \multicolumn{3}{|l|}{ Common Categories of Municipal waste* } \\
\hline Household waste & 57 & 95.00 \\
\hline Construction and demolition debris & 50 & 83.30 \\
\hline Sanitation residue & 10 & 16.70 \\
\hline Waste from streets & 32 & 53.30 \\
\hline
\end{tabular}

Table 3. Knowledge regarding Household waste $(n=60)$.

\begin{tabular}{lrr}
\hline Description & Number & Percent \\
\hline Categories of Household waste* & & \\
Plastic & 59 & 98.30 \\
Food waste & 56 & 93.30 \\
Paper products & 52 & 86.70 \\
Glass & 46 & 76.70 \\
Clothes & 44 & 73.30 \\
Collection of Household waste* & & \\
Plastic Bag & 48 & 81.70 \\
Waste Bin & 25 & 41.70 \\
Cartons & - & - \\
Dump pits & 4 & 6.70 \\
Municipal buckets & 3 & 5 \\
Others & - & - \\
Reason & & \\
To generate Income & 3 & 5.00 \\
To manage the waste efficiently & 52 & 86.70 \\
To Minimize the waste & 40 & 66.70 \\
To reuse the waste & 3 & 5.00 \\
\hline
\end{tabular}




\begin{tabular}{lrr}
\hline To recycle the waste & 3 & 5.00 \\
To prevent from harm & 34 & 56.70 \\
\hline Multiple responses* & &
\end{tabular}

Table 3 shows 48 (81.70\%) respondent answered plastic bag can be used to collect waste and $35 \%$ ) Respondent answered as Municipal Buckets. In categories of waste majority 59 (98.30\%) respondents selected plastic followed by food waste 56 (93.30) respondents and minority 44 (73.30\%) clothes. Majority $52(86.70 \%)$ respondents' knowledge regarding reason for the separating waste was "to manage waste efficiently" whereas minority $35 \%$ ) respondents answer was to generate income, reuse waste and to recycle the waste.

Table 4. Knowledge regarding Biodegradable waste $(n=60)$.

\begin{tabular}{lrr}
\hline Description & Number & Percent \\
\hline Meaning & 57 & 95.00 \\
Substance that break down into simpler & & \\
substances by microorganisms. & & \\
Common types of Biodegradable waste* & 26 & 43.30 \\
Wood/crumbles & 60 & 100.00 \\
Food waste & 43 & 71.70 \\
Paper waste & 40 & 66.70 \\
Yard/ green waste & 36 & 60.00 \\
Sewage / sewage sludge & 14 & 23.30 \\
Pieces of clothes & & \\
Method of waste disposal* & 4 & 6.70 \\
Collecting in Waste tank & 23 & 38.30 \\
Composting & - & - \\
Throwing outside house & 3 & 5.00 \\
Dumping in kitchen garden & - & - \\
Dumping in Road & - & - \\
Dumping in Rivers & 45 & 75.00 \\
Give in municipalities & & \\
\hline Multiple responses* & &
\end{tabular}

Table 4 shows knowledge regarding Biodegradable waste, majority 57 (95\%) respondents answered, "As Substance that break down into simpler substances by microorganisms". Majority 60 $(100 \%)$ respondent answered Food waste as common Biodegradable waste whereas 14 (23.30\%) respondents answered as Pieces of clothes. Majority 45 (75\%) respondent answered 'Give in municipality' 3 (5\%) Respondent answered as Dumping in kitchen garden as the management of Biodegradable waste.

Table 5 shows knowledge regarding Non-biodegradable waste, majority 54 (90\%) respondent answered, "As Substance that cannot be transformed into a natural harmless state". Majority 60 (100\%) respondent answered Plastic bags and water bottles as common Non-Biodegradable waste whereas 57 (95\%) respondents answered as Rubber tyres. 42 (70\%) respondent answered method of disposal for non-biodegradable as 'Recycling and proper disposal of item that cannot be reused or recycled. 
Table 5. Knowledge regarding Non-Biodegradable waste $(n=60)$.

\begin{tabular}{lrr}
\hline Description & Number & Percent \\
\hline Meaning & 54 & 90.00 \\
Substance that cannot be transformed into a & & \\
natural harmless state & & \\
Common non-biodegradable waste* & 60 & 100.00 \\
Plastic bags & 60 & 100.00 \\
Water bottles & 58 & 96.70 \\
Tins & 57 & 95.00 \\
Rubber tyres & & \\
Method of disposal* & 40 & 66.70 \\
Reduce our use of non-biodegradable products & 1 & 1.70 \\
Choose biodegradable alternatives whenever & & \\
possible & 7 & 11.70 \\
Reusing non-biodegradable items if possible. & 42 & 70.00 \\
Recycling them when possible. & 42 & 70.00 \\
Proper disposal of item that cannot be reused or & & \\
recycled. & & \\
\hline Multiple responses* & &
\end{tabular}

Table 6. Knowledge regarding Hazardous waste $(n=60)$.

\begin{tabular}{lrr}
\hline Description & Number & Percent \\
\hline Meaning & & \\
Waste that poses substantial or potential threats & 58 & 96.70 \\
to public health or the environment. & & \\
Common Hazardous Wastes* & & \\
Pesticides & 58 & 96.70 \\
Heavy metals & 36 & 60.00 \\
Petrol & 50 & 83.30 \\
Gas & 49 & 81.70 \\
Acids & 54 & 90.00 \\
Household cleaners & 48 & 80.00 \\
Paint residues & 23 & 38.30 \\
Electronics and pharmaceuticals & 2 & 3.30 \\
\hline Multiple response* & \multicolumn{3}{c}{}
\end{tabular}

Table 6 shows knowledge regarding Hazardous waste; majority 58 (96.70\%) respondent answered, "As Waste that poses substantial or potential threats to public health or the environment". Majority 58 (96.70\%) respondent answered Pesticides, only 2 (3.30\%) answered as Electronics and pharmaceuticals common hazardous waste.

Table 7 shows knowledge regarding waste management 49 (81.70) respondent answered as Composting whereas $30(50 \%)$ respondents answered consuming and discarding less. In Meaning of Recycling of waste, 51 (85\%) respondents answered, "As Process of converting waste materials into reusable objects to prevent waste". $43(71.70 \%)$ respondent answered advantage of recycling waste as "reduces the amount of manufacture to make new products" whereas minority $16(26.70 \%)$ respondent answered as Saves energy. 
Table 7. Knowledge regarding management of waste $(n=60)$.

\begin{tabular}{lcc}
\hline Description & Number & Percent \\
\hline Waste management* & & \\
Composting & 49 & 81.70 \\
Producing environmentally friendly & 45 & 75.00 \\
goods/products & & \\
Reusing items & 44 & 73.30 \\
Donating & 39 & 65.00 \\
Recycling & 33 & 55.00 \\
Consuming and discarding less & 30 & 50.00 \\
Meaning of recycling of waste & & \\
Process of converting waste materials into & 51 & 85.00 \\
reusable objects to prevent waste & & \\
Advantages of recycling waste* & & \\
Saves product & 41 & 68.30 \\
Reduces the amount of manufacture to make new & 43 & 71.70 \\
products & \multicolumn{2}{|c}{} \\
Save energy & 16 & 26.70 \\
Reduce global climate change & 30 & 50.00 \\
\hline Multiple responses* & \multicolumn{2}{l}{} \\
&
\end{tabular}

\subsection{Practice regarding waste management}

Table 9 shows that Majority 59 (98.30\%) respondent answered food waste whereas 3 (5\%) respondents answered metals and yard wastes as the types of waste collected from house. Similarly 48 $(81.70 \%)$ respondents used plastic bag whereas $3(5 \%)$ respondents used Municipal Buckets to keep the household waste. Majority 45 (75\%) respondent disposed household waste by giving in municipality whereas minority $3(5 \%)$ respondents disposed by dumping in kitchen garden.

Table 9. Practice related to household waste $(n=60)$.

\begin{tabular}{lrr}
\hline Description & Number & Percent \\
\hline Common Types of waste collected from house* & & \\
Paper and cartoons & 57 & 95.00 \\
Plastics & 57 & 95.00 \\
Food waste & 59 & 98.30 \\
Tins/cans & 15 & 25.00 \\
Glass & 12 & 20.00 \\
Metals, & 6 & 10.00 \\
Yard wastes & 3 & 5.00 \\
Woods & 3 & 5.00 \\
Collection of Household* & & \\
Plastic Bag & 48 & 81.70 \\
Waste Bin & 25 & 41.70 \\
Dump pits & 4 & 6.70 \\
Municipal buckets & 3 & 5.00 \\
Method of Household waste Disposal* & & \\
Collecting in Waste tank & 4 & 6.70 \\
Composting & 23 & 38.30 \\
Throwing outside house & - & - \\
Dumping in kitchen garden & 3 & 5.00 \\
Dumping in Road & - & - \\
Dumping in Rivers & - & - \\
Give in Municipality & 45 & 75.00 \\
\hline Multiple responses* & &
\end{tabular}


Table 10 shows practice regarding waste separation; 37 (61.70\%) respondents separated their waste whereas only 23 (38.30\%) did not separate their waste. 37 respondents separated their waste as biodegradable and non-biodegradable. Among 60 respondents, 32 (86.50\%) respondent's reason for separating waste was to manage the waste efficiently whereas $14(37.80 \%)$ respondents answered to minimize the waste.

Table 10. Practice regarding waste separation $(n=60)$.

\begin{tabular}{lrr}
\hline Description & Number & Percent \\
\hline Separation of waste & & \\
Yes & 37 & 61.70 \\
No & 23 & 38.30 \\
Ways of waste Separation (n=37) & - & \\
Mix in one bucket & 37 & 61.70 \\
Separate as biodegradable and non biodegradable & - & - \\
Separate as recyclable and non recyclable & - & - \\
Others & & \\
Reason for separating waste* & - & - \\
To generate Income & 32 & 86.50 \\
To manage the waste Efficiently & 14 & 37.80 \\
To minimize the waste & - & - \\
To reuse the waste & - & - \\
To recycle the waste & 20 & 54.10 \\
To prevent from harm & & \\
\hline
\end{tabular}

Table 11 shows that Majority 21 (66.70\%) respondent managed biodegradable waste by Composting and $2(3.30 \%)$ respondents give to municipality and dump in kitchen garden. Whereas majority $56(93.30 \%)$ respondent managed non-biodegradable waste by giving in municipality and minority $2(3.30 \%)$ respondents manage by reusing the process.

Table 11. Practice regarding waste management $(\mathrm{n}=60)$.

\begin{tabular}{lrr}
\hline Description & Number & Percent \\
\hline Management of Biodegradable waste* & & \\
Bury in land & 18 & 31.70 \\
Composting & 21 & 66.70 \\
Give to municipalities & 19 & 98.30 \\
Dump in Rivers & 1 & 1.70 \\
Dump in kitchen garden & 1 & 1.70 \\
Management of Non-Biodegradable waste* & & \\
Recycling & 4 & 6.70 \\
Reusing & 2 & 3.30 \\
Dumping in river & - & - \\
Dumping in kitchen garden & 3 & 5.00 \\
Give to municipality & 56 & 93.30 \\
\hline Multiple responses* & \multicolumn{3}{c}{}
\end{tabular}

Table 12 shows that in all household (100\%) only family members were responsible for disposing of waste and the method used to collect waste in community was Waste.

Table 12. Responsible person and method for waste collection $(n=60)$.

\begin{tabular}{lrr}
\hline Description & Number & Percent \\
\hline $\begin{array}{l}\text { Responsible person for disposing household } \\
\text { waste any family member }\end{array}$ & 60 & 100 \\
$\begin{array}{l}\text { Method used in community for waste } \\
\text { management waste van }\end{array}$ & 60 & 100 \\
\hline
\end{tabular}


Table 13 shows that majority 59 (98.30\%) respondent had moderate level of knowledge whereas 1 $(1.70 \%)$ respondent had low-level knowledge. The mean and standard deviation is 1.98 and 0.129 respectively.

Table 13. Knowledge level $(n=60)$.

\begin{tabular}{llrrrr}
\hline Description & Level & Number & Percent & Mean & $\begin{array}{r}\text { Standard } \\
\text { Deviation }\end{array}$ \\
\hline Level of Knowledge & & & & & \\
Below 24 & Low & 1 & 1.70 & 1.98 & 0.129 \\
$24-71$ & Moderate & 59 & 98.30 & & \\
\hline
\end{tabular}

Table 14 shows that majority 35 (58.30\%) respondent had poor practice level whereas 25 (4170\%) respondent had good practice level. The mean and standard deviation is 1.42 and 0.497 respectively.

Table 14. Practice Level $(n=60)$.

\begin{tabular}{llrrrr}
\hline Description & Level & Number & Percent & Mean & $\begin{array}{r}\text { Standard } \\
\text { Deviation }\end{array}$ \\
\hline Level of Practice & & & & & \\
Below 14 & Poor & 35 & 58.3 & 1.42 & 0.497 \\
$14-40$ & Good & 25 & 41.70 & & \\
\hline
\end{tabular}

Table 15. Association of knowledge with practice $(n=60)$.

\begin{tabular}{llll}
\hline Chi-square value & d.f & p-value & Remarks \\
\hline $\mathbf{1 . 4 2}$ & 1 & 0.41 & $\begin{array}{l}\mathrm{p}>0.05 \\
\text { (No association) }\end{array}$ \\
\hline
\end{tabular}

Table 15 reveals that there is no association between knowledge and Practice (chi-square $=1.42$ and $\mathrm{p}$ value $=0.41$ ) since $\mathrm{p}$-value $>0.05$ level of significance.

Table 16. Possible Disease due to improper waste disposal $(n=60)$.

\begin{tabular}{lrr}
\hline Description & Number & Percent \\
\hline Possible disease* & & \\
Malaria & 44 & 73.30 \\
Typhoid & 6 & 10.00 \\
Diarrhea & 58 & 96.70 \\
Cholera & 57 & 95.00 \\
Helminthosis & 6 & 10.00 \\
Dysentery & 51 & 85.00 \\
\hline Multiple responses* & &
\end{tabular}

Table 8 shows Among 60 respondents, 58 (96.70\%) respondent answered Common disease due to improper waste disposal as Diarrhoea followed by cholera 57 (95\%) respondents and only 6 (10\%) respondents answered as Helminthosis.

\section{Discussion}

The study focuses on the knowledge and practice regarding waste management among community people of Gokarneshwor ward-05. To achieve the objectives of the study, descriptive research design was adopted and purposive sampling technique was used to select the sample. The data was collected from 60 household responded by interview method.

The study revealed that the $61.70 \%$ respondents were of age group $18-40$ in which $68.30 \%$ female respondents in this study. The study revealed knowledge regarding waste in which majority respondents answered waste as unwanted or unusable things. Majority respondents (90\%) answered health care area as common area of waste generation. In categories of household waste, majority of respondents selected 
plastic (98.30\%) followed by food waste_(93.30\%) and only (73.30\%) responses as clothes. Similar study was conducted by Bernado (2008) showed that the types of household wastes commonly generated are food/kitchen wastes, papers, bottles, metals, and cans, boxes/cartons, glass bottles, cellophane/plastics, and yard/garden wastes.

Majority (81.70\%) of respondents answered plastic bag can be used to collect waste and only $3(5 \%)$ respondent answered as municipal Buckets. Majority (86.70\%) respondent's knowledge regarding reason for the separating waste was "to manage waste efficiently" whereas only 5\% respondents answered to generate income, reuse waste and to recycle the waste. The study showed knowledge regarding Biodegradable waste, 95\% respondents answered "As Substance that break down into simpler substances by microorganisms". All respondents answered Food waste as common Biodegradable waste whereas only $23.30 \%$ respondents answered as Pieces of clothes. Similarly $75 \%$ respondent answered management of biodegradable waste as 'Give in municipality' whereas only $5 \%$ respondent answered as dumping in kitchen garden. This finding is contradictory with a cross-sectional study conducted in Kersa Woreda, Eastern Ethiopia by Mengistie and Baraki (2010) to assess the status of household of waste management and hygiene practices shows that $66 \%$ households disposed solid waste in open dumps.

The study revealed that knowledge regarding non-biodegradable waste, majority (90\%) respondent answered as "Substance that cannot be transformed into a natural harmless state". All respondents answered plastic bags and water bottles as common non-biodegradable waste and $70 \%$ respondents answered method of management for non-biodegradable as 'Recycling and proper disposal of item that cannot be reused or recycled.

The study revealed that knowledge regarding Hazardous waste, which showed most of $(96.70 \%)$ respondents answered"As Waste that poses substantial or potential threats to public health or the environment and $96.70 \%$ respondents answered type of hazardous waste as pesticidesand only $3.30 \%$ answered as electronics and pharmaceuticals common hazardous waste.

The study revealed knowledge regarding waste management, $81.70 \%$ respondents answered as composting whereas half of respondents answered discarding. In Meaning of Recycling of waste, 85\% respondents answered, "As Process of converting waste materials into reusable objects to prevent waste". More than half of respondent answered advantage of recycling waste as "reduces the amount of manufacture to make new products".

The study revealed that most of $(96.70 \%)$ respondents answered common disease due to waste as Diarrhoea followed by cholera_(95\%)___ and 10\% respondents answered as worm infestation. Similar study conducted in Eastern Ethiopia by Mengistie and Baraki (2010) showed that waste could lead to spread of various diseases like malaria, viral fever, dengue etc.

The study reveals that majority (98.30\%) of respondents had moderate level of knowledge which is supported by a study conducted by Abikusno (2003) to determine household garbage management, specifically participation of 218 housewives, in Banjarsari village West Cilandak district of South Jakarta showed approximately $71 \%$ of active housewives had significantly moderate level of knowledge on garbage disposal.

In this study practice of waste separation, 37 (61.70\%) respondents separated their waste, Among the 37 respondents who separated their waste they separated as biodegradable and non-biodegradable. Half of the respondents answered reason for separating waste was to manage the waste efficiently whereas only $14(37.70 \%)$ respondents answered to minimize the waste

In the practice, $58.30 \%$ respondent had poor practice which differs from a study conducted in Ethiopia by Yemaneh, et al. (2017) showed that majority (76.9\%) of participants have good practice toward waste management.

\section{Conclusion}

The study concluded that majority respondent had moderate level of knowledge whereas

Majority of respondent had poor practice level. The study reveals that there is no association between knowledge and practice.

Conflicts of Interest: No conflict of interest. 


\section{References}

Abikusno, N. (2003). Household garbage management: participation of housewives, Banjarsari Village, West Cilandak District South Jakarta.

Asian Development Bank. (2013). Solid waste management in Nepal: Current status and policy recommendations. Asian Development Bank.

Babaei, A. A., Alavi, N., Goudarzi, G., Teymouri, P., Ahmadi, K., \& Rafiee, M. (2015). Household recycling knowledge, attitudes and practices towards solid waste management. Resour Conserv Recycl, 102, 94-100. doi:10.1016/j.resconrec.2015.06.014

Barloa, E. P., Lapie, L. P., \& de la Cruz, C. P. P. (2016). Knowledge, attitudes, and practices on solid waste management among undergraduate students in a Philippine State University. J Environ Earth Sci, 6(6), 146-53.

Bernardo, E. C. (2008). Solid-Waste Management Practices of Households in Manila, Philippines. Ann NY Acad Sci, 1140 (1), 420-424. doi:10.1196/annals.1454.016

Bhuiyan, S. H. (2010). A crisis in governance: Urban solid waste management in Bangladesh. Habitat Int, 34 (1), 125 133. doi:10.1016/j.habitat.2009.08.002

Das, S., \& Das, B. (2017). Waste Plastic's Green Construction: Introducing the Process that Converts $100 \%$ Plastic Waste Into An Alternative Renewable Various Types Of Construction Materials. EJBPS, 4(12), 307-319.

Guerrero, L. A., Maas, G., \& Hogland, W. (2013). Solid waste management challenges for cities in developing countries. Waste management, 33(1), 220-232. doi:10.1016/j.wasman.2012.09.008

Iwu, A. C., Duru, C. B., Uwakwe, K. A., Diwe, K. C., Merenu, I. A., Emerole, C. A., \& Chineke, H. N. (2016). Assessment of waste management practices among traders in major markets in Owerri, Imo state, Nigeria. IJHSR, 6, 7-17.

Jin, J., Wang, Z., \& Ran, S. (2006). Solid waste management in Macao: practices and challenges. Waste management, 26 (9), 1045-1051. doi:10.1016/j.wasman.2005.08.006

Laor, P., Suma, Y., Keawdounglek, V., Hongtong, A., Apidechkul, T., \& Pasukphun, N. (2018). Knowledge, attitude and practice of municipal solid waste management among highland residents in Northern Thailand.J Health Res, 32 (2), 123-131. doi:10.1108/JHR-01-2018-013

Mengistie, B., \& Baraki, N. (2010). Community based assessment on household management of waste and hygiene practices in Kersa Woreda, Ethiop J Health Dev, 24 (2). doi:10.4314/ejhd.v24i2.62958

Pandey, R. (2004). Solid Waste Management Practice and Health Implication: A Case of Kathmandu Metropolitan City, Nepal. Himalayan Rev, 35-36 33-47.

Pokhrel, D., \& Viraraghavan, T. (2005). Municipal solid waste management in Nepal: practices and challenges. Waste Management, 25 (5), 555-562. doi:10.1016/j.wasman.2005.01.020

Shekdar, A. V. (2009). Sustainable solid waste management: an integrated approach for Asian countries. Waste management, 29 (4), 1438-1448. doi:10.1016/j.wasman.2008.08.025.

Yemaneh, Y., Abera, T., Hailu, D., Niguse, W., Chewaka, L., Daniel, T., ... \& Tsegaye, N. (2017). Knowledge Attitude and practice towards solid and liquid waste Management among Addis ketema and Kometa kebele community Mizan-Aman town, Bench-Maji zone, South Nations Nationalities and Peoples Regional State, South West Ethiopia, 2017. J Environ Geol 1 (1), 17. 